
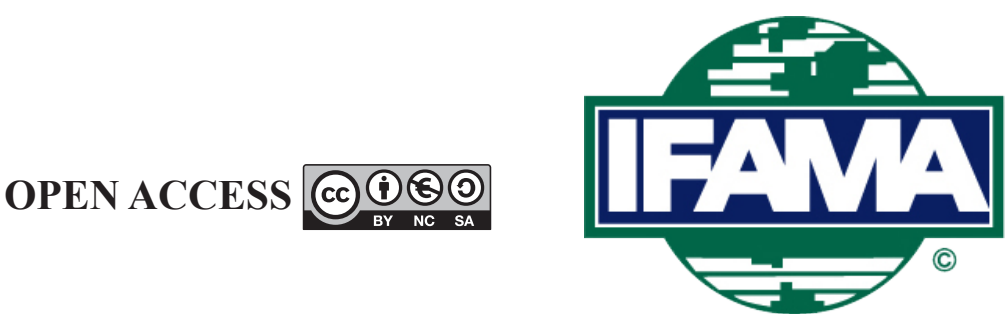

International Food and Agribusiness Management Review

Volume 23, Issue 3, 2020; DOI: 10.22434/IFAMR2019.0212

Received: 20 December 2019 / Accepted: 30 April 2020

\title{
Hedonic valuation of country of origin in the Chinese dairy market
}

\author{
RESEARCH ARTICLE \\ Yan Zhang ${ }^{\mathrm{a}}$ and Shaosheng Jin ${ }^{\circledR b}$ \\ ${ }^{a}$ Doctor and Lecturer, State Key Laboratory of Grassland Agro-ecosystems, College of Pastoral Agriculture Science \\ and Technology, Lanzhou University, 222 Tianshui Road, Chengguan District, Lanzhou 730000, China P.R. \\ ${ }^{b}$ Doctor and Professor, China Academy for Rural Development (CARD), Zhejiang \\ University, No. 866 Yuhangtang Road, Xihu District, Hangzhou 310058, China P.R.
}

\begin{abstract}
The implicit value to Chinese consumers of the country-of-origin (COO) characteristic of dairy products is of great importance to estimate. This study adopted the hedonic price model to evaluate the shadow price of the $\mathrm{COO}$ attribute of both UHT fluid milk and infant formula collected from the five leading e-commerce platforms (Alibaba's Tmall Supermarket, Jingdong, Suning Purchase, COFCO I buy nets, and Yihaodian) in China. The target countries were Germany, France, the Netherlands, and Spain from the EU, and Australia and New Zealand from Oceania. The results show that the implicit values of the COO of UHT fluid milk and infant formula are reversed. Having a COO of Spain and Germany decreased the price of UHT fluid milk compared with China, while Germany, New Zealand, France, the Netherlands, and Spain all earned a price premium on infant formula. The B2C platforms Yihaodian, Jingdong, Alibaba's Tmall Supermarket and Suning Purchase all earned a price premium above COFCO I buy nets. These findings have important implications for dairy industry of EU countries, Australia, New Zealand, and China in terms of the promotion of domestic dairy products. Moreover, this study contributes to the existing body of literature by innovating in employing sales data from e-commerce scanners to study the implicit value of food attributes.
\end{abstract}

Keywords: country-of-origin, B2C platform, implicit value, hedonic price analysis, dairy product JEL code: D12, L81

\footnotetext{
(1)Corresponding author: ssjin@zju.edu.cn
} 


\section{Introduction}

Urban China has witnessed a rapid growth of dairy consumption from the 1990s to 2008 as a result of income growth, expansion of modern food retailers or marketing channels, the trend of higher education levels, and changes in urban lifestyles (Bai et al., 2008; Cheng et al., 2014; Fuller et al., 2006; Wu et al., 2014). According to the China Dairy Yearbook (1996-2018), the average annual dairy consumption of urban residents was 7.33 $\mathrm{kg}$ in 1995 , which increased to $24.87 \mathrm{~kg}$ in 2007 . However, this growth trend for the Chinese domestic dairy market was negatively impacted by the melamine scandal in 2008 (Dong and Li, 2016). Thus, consumption of dairy products declined to $16.5 \mathrm{~kg}$ in 2017 - much lower than the consumption in 2007.

Although the average annual consumption was decreasing, the import of both milk powder and fluid milk in China accelerated rapidly during 2008 to 2017. The average annual growth rates were 24.4 and $63.9 \%$, respectively (Figure 1). This is in line with the prediction from Fuller et al. (2006) that imported products would likely play an increasing role in China's dairy market. Two major factors led to the sharp increase in dairy imports in China. Firstly, the loss of confidence by Chinese consumers in domestic dairy products due to the melamine scandal in 2008, this incident has made Chinese consumers overwhelmingly concerned about China's food safety situation (Bai et al., 2013), and the safety of dairy products has become one of the top food safety concerns in China (Jia et al., 2012, 2014; Qiao et al., 2010; Tao et al., 2016; Xiu and Klein, 2010; Yu, 2012). Consumers tend to take measures to reduce food risk (Baron et al., 2000), thus imported products are a desirable substitute for domestic products. Secondly, the online market is growing rapidly in China and it is expected to be the biggest online market in 2019 (Jiang et al., 2019), therefore e-commerce is becoming increasingly important for Chinese consumers, which is making it easier for Chinese consumers to access imported dairy products.

Country of origin labelling (COOL) serves as an extrinsic cue to indicate quality and safety, and it influences consumers' preferences and food choices (Agrawal and Kamakura, 1999; Bonroy and Constantatos, 2015; Deselnicu et al., 2013; Hussein and Fraser, 2018). Herrmann and Teuber (2012) claimed that the use of COOL has increased due to the growing concern and awareness about food quality and safety, since many consumers place extra value on the traceability of the food they eat. Wang et al. (2019) found that COO is the most important attribute of milk power for Chinese consumers. China imports the vast majority of its

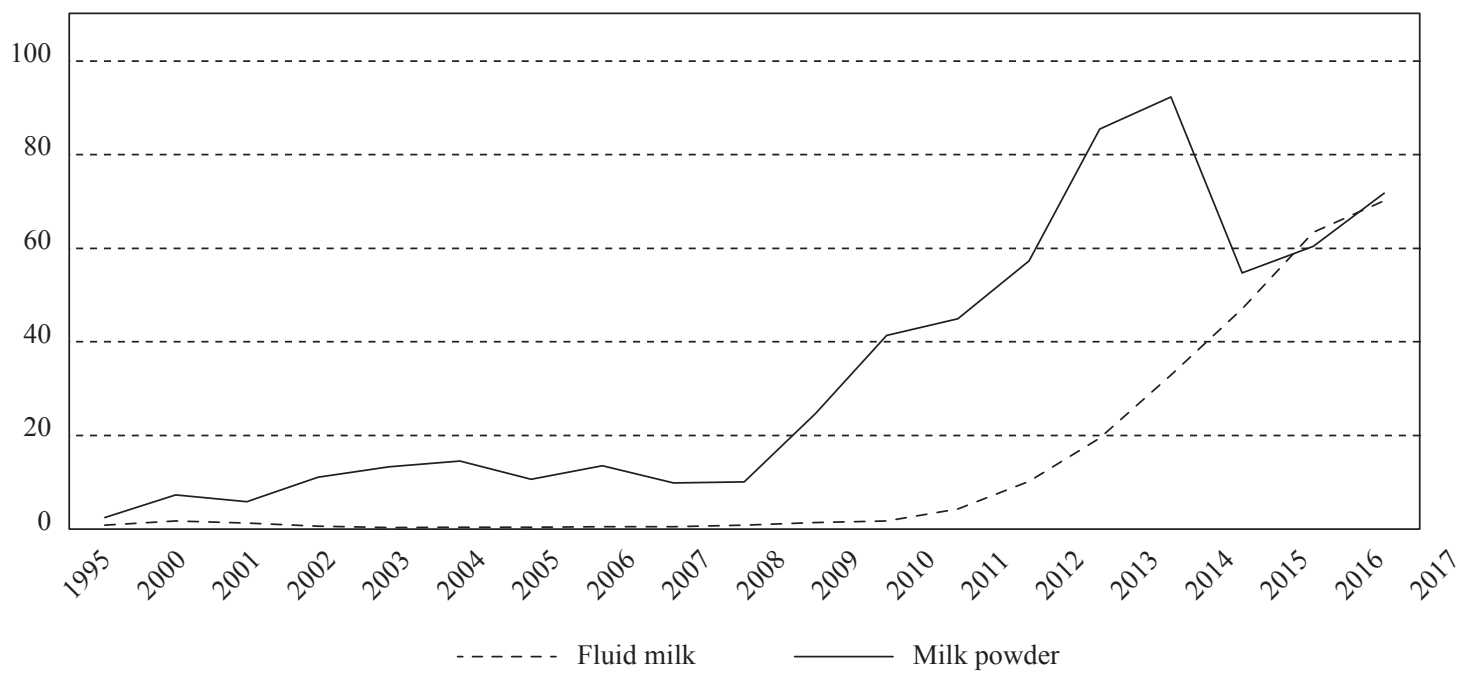

Figure 1. The import of fluid milk and milk powder into China (unit: $10^{4}$ tons). Data from 1995 to 2010 is adapted from the China Dairy Yearbook (CMYEB, 2012), and the data from 2011 to 2017 comes from the China Dairy Trade Monthly (DAC, 2018). 
dairy products from the European Union, Australia, and New Zealand. The EU cancelled its dairy production quota in 2015 and the Chinese government signed a free trade agreement with New Zealand and Australia, as the international dairy market is increasingly competitive. Thus, it is imperative to clarify the shadow price or implicit price of the different COOL of the major trading countries, which may have marketing implications for the Chinese dairy sector.

Several studies have investigated the impact of COOL of food products on consumers. According to Newman et al. (2014), COO information was found to often have strong effects on consumer attitudes, evaluations, perceptions, preferences, willingness-to-pay (WTP), purchase intentions, and purchase behavior. Prior studies have claimed that in developed countries consumer attitudes seem more positive to domestic food than imported, and domestic food is perceived to be of higher quality and safer, thus it is preferred over imported options. The relationship between quality and COOL is strong, particularly for fresh and perishable products (Tsiros and Heilman, 2005). However, the preference is the opposite in emerging or less-developed countries (Ortega et al., 2016; Zhang et al., 2018).

In terms of the WTP for food COOL information, US consumers are willing to pay more for domestic food such as steak and aquatic products (Lim et al., 2013; Ortega et al., 2014; Umberger et al., 2002). Loureiro and Umberger (2003) claimed that US households were willing to offer about \$184 more for COO information annually; they would pay a $\$ 0.31 / \mathrm{lb}$ price premium for domestic organic broccoli over Canadian-grown organic broccoli, and this premium would be more than $\$ 1$ when compared with organic broccoli from China and Mexico (Xie et al., 2016). They also reported being willing to pay a $\$ 6.94 / 1 \mathrm{~b}$ and $\$ 6.53 / \mathrm{lb}$ price premium for domestic shrimp, with enhanced perceived food safety, than for the same shrimp from China and Thailand, respectively (Ortega et al., 2014). Similarly, Norwegian consumers would offer an NOK 20 per kilogram price premium for domestic beef in comparison to US beef (Ortega et al., 2014), and consumers from France, Denmark, Sweden, and the UK would pay approximately 5\% more for domestic pork (Dransfield et al., 2005). Consumer ethnocentrism, safety concerns, taste and flavor, among other considerations, are the main factors influencing the higher WTP for domestic foods in developed countries (Lewis and Grebitus, 2016; Peterson and Yoshida, 2004; Umberger et al., 2002). These factors are from the perspective of consumers' subjective attitudes or perceptions.

The previous studies based on Chinese dairy consumption have made a notable contribution to the literature around Chinese consumer preferences and valuation of food safety attributes (Bai et al., 2007, 2013; Cheng et al., 2014; Gao et al., 2016; Luo, 2011; Ortega et al., 2012; Quan et al., 2018; Wang et al., 2019; Zhang et al., 2012, 2018). These studies found that Chinese consumers are willing to pay for sustainable milk (Gao et al., 2016) and green certified milk (Cheng et al., 2014). They also are willing to pay a price premium for milk with government certification over products with a brand or private certification, but they have a negative WTP for UHT fluid milk with a shelflife longer than three months (Ortega et al., 2012). Chinese consumers also had a strong desire and higher price premium for traceable milk (Bai et al., 2013; Zhang et al., 2012), and this was related to the certificate issuers (Bai et al., 2013). Quan et al. (2018) found that Chinese consumers have an 11.6 to $47.0 \%$ higher WTP for imported baby milk formula, and they would like to buy branded fresh milk or milk with quality certifications (Ding and Michele, 2019). In terms of research methods, these researchers mainly adopted the stated preference methods such as CVM (Cheng et al., 2014; Gao et al., 2016; Wang et al., 2008; Zhang et al., 2012), choice experiments (Ortega et al., 2012; Quan et al., 2018) or choice-based conjoint (CBC) experiments (Bai et al., 2007, 2013), and auction experiments (Zhang et al., 2018), and the study areas were often localized or confined to urban areas. Little attention has been given to estimating the economic value that consumers place on dairy product safety attributes by employing nationwide sales data.

The primary objective of this study is to estimate the implicit value Chinese consumers place on COOL, and the effect of other attributes of UHT fluid milk and infant formula on market price from different countries and different e-commerce platforms. To accomplish this, the hedonic model of prices as a function of product attributes is adopted. This study is based on the sale prices and attributes of both UHT fluid milk and infant 
formula collected from the five leading e-commerce platforms in China: Alibaba's Tmall Supermarket, Jingdong, Suning Purchase, COFCO I buy nets, and Yihaodian. This study contributes to the existing body of literature as it, contrary to most studies, uses real sales data in the form of nationwide e-commerce scanner data, and the revealed preference methods with real purchase data more truthfully reflect consumer preference and choice in the real market than do stated preference methods (Gao et al., 2016). Furthermore, it includes two categories of dairy products, UHT fluid milk and infant formula, thereby contributing a better understanding of consumer behavior in dairy product purchasing decisions in a retail environment characterized by a vast number of alternative options from different countries.

\section{Model and data}

\subsection{Model}

Lancaster proposed a theory that a product is regarded as a combination of multiple characteristics. Products can be distinguished simply and uniquely by their characteristics, and that utility is derived from the properties or characteristics of goods (Lancaster, 1966). This theory is the basic conceptual framework of hedonic price analysis (Huang and Lin, 2007). Hedonic price analysis is usually adopted to estimate the implicit values of food and beverage attributes (Hussein and Fraser, 2018; Ladd and Martin, 1976; Ladd and Suvannunt, 1976), based on the premise that the bundled product attributes are not marketed individually (Costanigro et al., 2010). Consumers and producers, in a market with perfect information and product differentiation, recognize product attributes in approximately the same ways (Huang and Lin, 2007), and equilibrium prices will depend on differences in product attributes, but the individual actors cannot affect the prices (Costanigro et al., 2010).

From the perspective of the consumer, the utility of a product with the attributes $\mathrm{z}=\left(\mathrm{z}_{1}, \ldots, \mathrm{z}_{\mathrm{k}}\right)$ can be functioned as:

$$
\mathrm{U}=\mathrm{U}\left(\mathrm{x}, \mathrm{z}_{1}, \ldots, \mathrm{z}_{\mathrm{n}} ; \alpha\right)
$$

where $\mathrm{x}$ is a composite good with the normalized unit price and $\alpha$ denotes preference.

The budget constraint is:

$$
y=x+P(z)
$$

where $y$ is income, and the hedonic price function $\mathrm{P}(\mathrm{z})$ describes the competitive equilibrium price relationship reached simultaneously by both the supply and demand of a collection of attributes.

$$
\mathrm{P}(\mathrm{z})=\mathrm{P}\left(\mathrm{z}_{1}, \ldots, \mathrm{z}_{\mathrm{n}}\right)
$$

Mathematically, maximization of the utility function is subject to the budget constraint, and must satisfy the first order conditions:

$$
\frac{\left(\delta \mathrm{U} / \delta \mathrm{z}_{\mathrm{k}}\right)}{(\delta \mathrm{U} / \delta \mathrm{x})}=\frac{\delta \mathrm{P}(\mathrm{z})}{\delta \mathrm{z}_{\mathrm{k}}}=\mathrm{P}_{\mathrm{z}_{\mathrm{k}}}, \mathrm{i}=1, \ldots, \mathrm{n}
$$

$\mathrm{Pz}_{\mathrm{k}}$ is the marginal implicit value for attribute $\mathrm{z}_{\mathrm{k}}$. The price paid by the consumer for each product consumed equals the sum of the marginal monetary values of the product's characteristics (Ladd and Suvannunt, 1976).

With regard to the functional form of the dependent variable, previous literature provides no theoretical guidance (Carew and Florkowski, 2010; Edenbrandt et al., 2018). The most basic specification the estimated hedonic function takes is the following linear form:

$$
\mathrm{P}_{\mathrm{i}}=a_{0}+\sum_{k=1}^{K} \beta_{k} z_{k i}+\varepsilon_{i}
$$


where $z_{k}$ is the attribute vector of product $i$. However, the chosen functional forms vary widely and often include non-linear transformations of the dependent variable, the independent variables, or their interaction, so hedonic and implicit price functions can be expected to be non-linear (Costanigro and McCluskey, 2011; Ekeland et al., 2002, 2004). Regarding the non-negativity and right-skewness features of parametric distribution of product prices is consistent with the log-normal distribution. Then, the logarithmic transformation of the dependent variable can be depicted as:

$$
\ln P_{i}=a_{0}+\sum_{k=1}^{K} \beta_{k} z_{k i}+\varepsilon_{i}
$$

\subsection{Data and statistics}

The data were collected from emerging modern food marketing channels: the e-commerce platforms in China, between late February and early March 2017. For all the self-operated UHT fluid milk and infant formula sales of the five platforms, the price and other characteristics or attributes were carefully recorded. Each observation represents a product. The attributes are recorded and their definitions are exhibited in Table 1.

Table 1. Description of variables.

\begin{tabular}{|c|c|c|}
\hline Variables & Type & Description \\
\hline \multicolumn{3}{|l|}{ Dependent variable } \\
\hline Price & Continuous & Yuan per $200 \mathrm{ml}$ for UHT fluid milk and $200 \mathrm{~g}$ for infant formula \\
\hline \multicolumn{3}{|l|}{ Independent variables } \\
\hline Country-of-origin & Categorical & $\mathrm{CHN}=1, \mathrm{GER}=2, \mathrm{NZL}=3, \mathrm{FRA}=4, \mathrm{AU}=5, \mathrm{NED}=6, \mathrm{ESP}=7$ \\
\hline B2C Platforms & Categorical & $\begin{array}{l}\text { COFCO I buy nets }=1 \text {, Yihaodian }=2 \text {, Jingdong }=3 \text {, Alibaba's Tmall } \\
\text { Supermarket }=4 \text {, Suning Purchase }=5\end{array}$ \\
\hline Brand & Categorical & $\begin{array}{l}\text { For UHT fluid milk: Yili }(\mathrm{CHN})=1 \text {, Sanyuan }(\mathrm{CHN})=2 \text {, SUNSIDES } \\
(\mathrm{GER})=3 \text {; Satine of Yili }(\mathrm{CHN})=4 \text {; Shengmu }(\mathrm{CHN})=5 \text {, Anchor } \\
(\mathrm{NZL})=6 \text {; Devondale }(\mathrm{AU})=7 \text {; Weidendorf }(\mathrm{GER})=8 \text {; Oldenburger } \\
(\mathrm{GER})=9 \text {; Muh-Metro }(\mathrm{GER})=10 \text {; Muh-Gump's ranch }(\mathrm{GER})=11 \text {; } \\
\text { MeadowFresh }(\mathrm{NZL})=12 ; \text { ATO }(\mathrm{ESP})=13 \text {; Mengniu }(\mathrm{CHN})=14 \text {; Deluxe } \\
\text { of Mengniu }=15 ; \text { Others }=16 \text {; for infant formula: Biostime }(\mathrm{CHN})=1 \text {; } \\
\text { Junlebao }(\mathrm{CHN})=2 \text {; Wandashan }(\mathrm{CHN})=3 \text {; Wyeth }=4 \text {; Aptamil }(\mathrm{GER})=5 \text {; } \\
\text { Friso }(\mathrm{NED})=6 \text {; MeadJohnson }(\mathrm{USA})=7 \text {; Nutrilon }(\mathrm{NED})=8 \text {; Beingmate } \\
(\mathrm{CHN})=9 \text {; Nestlé (Switzerland })=10 \text {; Similac }(\mathrm{USA})=11 ; \text { Others }=12\end{array}$ \\
\hline Discount & Dummy & Discount $=1$, otherwise $=0$ \\
\hline Salesize & Continuous & Sales unit, UHT fluid milk in ml; infant formula in grams \\
\hline Shelflife & Continuous & Quality guarantee period marked in the package (month) \\
\hline Organic & Dummy & Organic $=1$, otherwise $=0$ \\
\hline Traceability & Dummy & Traceability $=1$, otherwise $=0$ \\
\hline Introduction_source & Dummy & Introduction of the source of raw milk $=1$, otherwise $=0$ \\
\hline Other_credentials & Dummy & Other credentials $=1$, otherwise $=0$ \\
\hline Protein & Continuous & $\begin{array}{l}\text { For UHT fluid milk, the mass of protein per } 100 \mathrm{ml} \text {; for infant formula, } \\
\text { the mass of protein per } 100 \mathrm{~g}\end{array}$ \\
\hline Milk_fat & Continuous & $\begin{array}{l}\text { For UHT fluid milk, the mass of milk fat per } 100 \mathrm{ml} \text {; for infant formula, } \\
\text { the mass of milk fat per } 100 \mathrm{~g}\end{array}$ \\
\hline Calcium & Continuous & $\begin{array}{l}\text { For UHT fluid milk, the mass of Calcium per } 100 \mathrm{ml} \text {; for infant formula, } \\
\text { the mass of Calcium per } 100 \mathrm{~g}\end{array}$ \\
\hline Reconstituted_milk & Dummy & Reconstituted milk $=1$, otherwise $=0$ \\
\hline Stage & Categorical & $\begin{array}{l}\text { Stage of infant formula, the first stage }=1 \text {; the second stage }=2 ; \text { the third } \\
\text { stage }=3 \text {, the fourth stage }=4\end{array}$ \\
\hline
\end{tabular}


According to Jiang et al. (2019), Alibaba's Tmall is the biggest e-commerce B2C platform in China, with a market share of $65.2 \%$, followed by Jingdong and Suning Purchase with shares of 23.2 and $5.3 \%$, respectively. The other online platform was COFCO I buy nets, which is also an important and professional online food retailer established by China Oil \& Foodstuffs Corporation (COFCO for short). Moreover, another platform used was Yihaodian, which is also an important online food retailer, accounting for $37.2 \%$ of the market share of imported dairy products sold in China in 2013. All consumers have access to these platforms theoretically, so the data can be regarded as representative. The initial sample sizes for UHT fluid milk and infant formula were 927 and 776, respectively. In this study, we focused on the top six original countries (Germany, New Zealand, France, Australia, the Netherlands, and Spain), alongside China. After excluding outliers, the final samples of UHT fluid milk and infant formula were 797 and 636, respectively. The summary statistics of the sample are shown in Table 2.

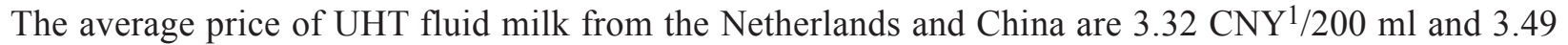
CNY/200 ml, respectively, far exceeding that of Australia, Germany, and especially Spain. In the case of infant formula, the price for the Chinese brand is the lowest, $27.3 \%$ less than the formula from New Zealand, and $49.1 \%$ less than formula from France.

\section{Results and discussion}

To emphasize the importance of $\mathrm{COO}$ and other characteristics with regard to dairy prices, UHT fluid milk and infant formula were both included in the analysis. First, we specified the models for both UHT fluid milk and infant formula. Second, the implicit price of COO was examined and the results of UHT fluid milk and infant formula are reported.

\subsection{Model specification}

Though the log-linear hedonic model is the most commonly used, model specification should be implemented by estimating several alternative forms. According to Costanigro et al. (2007) and Costanigro and Mccluskey (2011), this paper specified several transformations of the dependent variable in terms of heteroscedasticity, misspecification, and normality of the residuals ${ }^{2}$. Then, the adequate or 'best' models were chosen. We found that the natural log form was the best performing transformation for UHT fluid milk, and the simple linear was adequate for infant formula.

The price function for the UHT fluid milk takes the following form:

$$
\begin{aligned}
\ln \left(\text { Price }_{i}\right) & =\beta_{0}+\beta_{1} \text { COO }_{i}+\beta_{2} \text { Brand }_{i}+\beta_{3} \text { Platform }_{i}+\beta_{4} \text { Salesize }_{i}+\beta_{5} \text { Shelflife }_{i} \\
& +\beta_{6} \text { Organic }_{i}+\beta_{7} \text { Traceability }_{i}+\beta_{g} \text { Introduction_Source }_{i} \\
& +\beta_{9} \text { Other_credentials }_{i}+\beta_{10} \text { Protein }_{i}+\beta_{11} \text { Discount }_{i}+\beta_{12} \text { Calcium }_{i} \\
& +\beta_{13} \text { Milk_fat }_{i}+\beta_{14} \text { Reconstituted_milk }_{i}+\varepsilon_{i}
\end{aligned}
$$

The price function for the infant formula is the following:

$$
\begin{aligned}
\ln \left(\text { Price }_{i}\right) & =\beta_{0}+\beta_{1} \mathrm{COO}_{i}+\beta_{2} \text { Brand }_{i}+\beta_{3} \text { Platform }_{i}+\beta_{4} \text { Salesize }_{i}+\beta_{5} \text { Shelflife }_{i} \\
& +\beta_{6} \text { Organic }_{i}+\beta_{7} \text { Traceability }_{i}+\beta_{8} \text { Introduction_Source }_{i} \\
& +\beta_{9} \text { Other_credentials }_{i}+\beta_{10} \text { Protein }_{i}+\beta_{11} \text { Discount }_{i}+\beta_{12} \text { Calcium }_{i} \\
& +\beta_{13} \text { Milk_fat }_{i}+\beta_{14} \text { Stage }_{i}+\varepsilon_{i}
\end{aligned}
$$

\footnotetext{
${ }^{1}$ In February and March 2017, the average exchange rate was 1 US $\$=6.8823 \mathrm{CNY}$.

2 The RESET test was used to test model misspecification; the Breusch-Pagan test was used for heteroscedasticity; and the Kurtosis test, ShapiroWilk test, and Shapiro-Francia test were used to test for normality of residuals.
} 
Since UHT fluid milk is liquid and infant formula is a milk power, different attributes are included. Reconstituted milk is a special type of UHT fluid milk, and for each 'stage' it is specific to infant formula for babies of different ages, for whom different stages of milk power should be selected. Separate models were estimated for UHT fluid milk and infant formula.

\subsection{UHT fluid milk}

The results of UHT fluid milk model estimates are reported in Table 3 (Model 1), and the model with the simple linear form of the dependent variable was also conducted as a robust test (Model 2). Model 1 and Model 2 have $\mathrm{R}^{2}$ values of 0.466 and 0.432 , respectively, which suggests that the independent variables of these two models can explain more than $45 \%$ of the variation of the dependent variable, and indicates that both the models have a good fit.

Table 3. Results of the hedonic model for UHT fluid milk. ${ }^{1}$

\begin{tabular}{|c|c|c|}
\hline Variables & $\begin{array}{l}\text { Model } 1 \\
\text { Coefficient }\end{array}$ & $\begin{array}{l}\text { Model } 2 \\
\text { Coefficient }\end{array}$ \\
\hline Dependent variable & Ln (price) & price \\
\hline Brand $^{2}$ & controlled & controlled \\
\hline \multicolumn{3}{|l|}{ Country-of-origin } \\
\hline CHN & - & - \\
\hline GER & $-0.206 * * *(-2.71)$ & $-0.395 *(-1.67)$ \\
\hline NZL & $0.069(0.71)$ & $0.222(0.73)$ \\
\hline FRA & $-0.098(-1.28)$ & $-0.146(-0.62)$ \\
\hline $\mathrm{AU}$ & $-0.098(-1.52)$ & $-0.066(-0.33)$ \\
\hline NED & $0.093(0.87)$ & $0.404(1.21)$ \\
\hline ESP & $-0.409 * * *(-2.76)$ & $-1.020 * *(-2.22)$ \\
\hline \multicolumn{3}{|l|}{ B2C Platforms } \\
\hline COFCO I buy nets & - & - \\
\hline Yihaodian & $0.143 * * *(2.86)$ & $0.394 * *(2.55)$ \\
\hline Jingdong & $0.157 * * *(3.22)$ & $0.521 * * *(3.43)$ \\
\hline Alibaba'sTmall Supermarket & $0.245 * * *(5.06)$ & $0.764 * * *(5.07)$ \\
\hline Suning Purchase & $0.194 * * *(3.61)$ & $0.553 * * *(3.31)$ \\
\hline \multicolumn{3}{|l|}{ Controlled variables } \\
\hline Salesize & $-0.00004 * * *(-12.95)$ & $-0.00001 * * *(-11.50)$ \\
\hline Shelflife & $-0.022 * *(-2.04)$ & $-0.098 * * *(-2.88)$ \\
\hline Protein & $0.195 * *(2.46)$ & $0.732 * * *(2.96)$ \\
\hline Organic & $0.270 * * *(4.33)$ & $0.823 * * *(4.25)$ \\
\hline Traceability & $0.087(1.09)$ & $0.283(1.15)$ \\
\hline Introduction_source & $-0.027(-1.02)$ & $-0.047(-0.57)$ \\
\hline Other_credentials & $-0.047(-1.44)$ & $-0.153(-1.50)$ \\
\hline Discount & $-0.134 * *(-2.04)$ & $-0.307(-1.50)$ \\
\hline Calcium & $0.003(1.17)$ & $0.009(1.14)$ \\
\hline Milk_fat & $0.008(0.76)$ & $0.025(0.82)$ \\
\hline Reconstituted milk & $-0.039(-0.62)$ & $-0.172(-0.87)$ \\
\hline Constant & $0.077(0.26)$ & $-0.276(-0.31)$ \\
\hline $\mathrm{N}$ & 797 & 797 \\
\hline R-squared & 0.466 & 0.432 \\
\hline
\end{tabular}

${ }^{1} t$-statistics are in parentheses; $*, * *, * * *$ indicate statistical significance at the 10,5 and $1 \%$ levels, respectively.

2 The regression result of Brand has been withheld to protect privacy. 
It is revealed from Model 1 and 2 that Spain and Germany have significantly negative coefficients, implying that, compared to China, the imported UHT fluid milk from Germany and Spain has lower prices, ranging from 20.6 to $40.9 \%$ less than that of China in a perfect competition market. That is to say, the COOL of imported milk, especially for milk from Germany, did not earn positive implicit value under fierce competition. However, this objective implicit price with negative significance (especially Germany) is inconsistent with the stated preference (subjective WTP) of Zhang et al. (2018), who adopted a BDM auction mechanism to elicit Chinese consumers' evaluations of UHT fluid milk from Australia, New Zealand, Germany and France compared with China. They found that Chinese consumers have a stated WTP premium of over 50\% for UHT fluid milk imported from the studied four countries. This discrepancy may be triggered by the distrust in Chinese domestic dairy products; Chinese consumers in this study evaluated the image of German dairy industry as better than that of the Chinese industry, so were willing to pay a higher price for the imported milk (Zhang et al., 2018). As the importation of UHT fluid milk in China is increasing and the international competition is fierce in the context of globalization and trade openness, the COOL of UHT fluid milk from the European Union, Australia and New Zealand will probably lead to a higher implicit value in future.

The regression results reveal that compared with COFCO I buy nets, Yihaodian, Jingdong, Alibaba's Tmall Supermarket and Suning Purchase all have significantly positive coefficients for the two models, implying a positive price premium (about 14 to $25 \%$ ) for these four B2C platforms. Attributes like organic, protein and short shelflife also earned a price premium.

\subsection{Infant formula}

The results of the UHT fluid milk model estimates are reported in Table 4 (Model 3), and the model with a natural $\log$ form of the dependent variable was also conducted as a robust test (Model 4). Model 3 and 4 have $\mathrm{R}^{2}$ values of 0.549 and 0.543 , respectively, which suggests that the independent variables of these two models can explain about $55 \%$ of the variation of the dependent variable, and indicates that both the models have a good fit, and also that the results of Model 3 and 4 are consistent.

The results show that, compared with China, infant formula from Germany, New Zealand, France, the Netherlands and Spain all earn higher price premium, which suggests that Chinese consumers prefer imported infant formula. This finding is in accordance with Wang et al. (2019), who found that Chinese consumers perceived COO as the most important attribute. As Luo (2011) reported, most Chinese consumers purchase foreign milk powder brands rather than Chinese ones, and they perceive the price to be the least important cue in infant formula evaluations and were indifferent to paying higher prices for it. The probable reason for this is that infant formula has special targeted groups. When the 2008 melamine scandal first broke out in relation to Chinese Sanlu infant formula, it destroyed the confidence of Chinese consumers, leading to a sharp increase in imports of infant formula. The coefficient value also suggests that consumers give more value to European countries (Germany, France, the Netherlands and Spain) than Oceania countries (Australia and New Zealand). The probable reason for this is the free trade agreements between China and Australia (in 2015) and New Zealand (in 2018), and also due to Clostridium botulinum being discovered in the products of dairy giant Fonterra from New Zealand in 2013, which might have had an adverse impact on the company's reputation and consumers' valuation of dairy products from these countries.

In terms of the B2C platforms, the price of infant formula from Yihaodian, Jingdong, Alibaba's Tmall Supermarket and Suning Purchase all have a positive premium of about $20 \%$ more than COFCO I buy nets. The organic attribute endows infant formula with about a $20 \%$ price premium.

\subsection{UHT fluid milk and infant formula}

For both UHT fluid milk and infant formula, the price of products sold on Yihaodian, Jingdong, Alibaba's Tmall Supermarket and Suning Purchase platforms were typically higher than those sold on COFCO I buy nets. The probable reason for this is that COFCO I buy nets is a special website dedicated to shopping food 
Table 4. Results of the hedonic model for infant formula. ${ }^{1}$

\begin{tabular}{|c|c|c|}
\hline Variables & $\begin{array}{l}\text { Model } 3 \\
\text { Coefficient }\end{array}$ & $\begin{array}{l}\text { Model } 4 \\
\text { Coefficient }\end{array}$ \\
\hline Dependent variable & price & $\ln ($ price $)$ \\
\hline Brands $^{2}$ & controlled & controlled \\
\hline \multicolumn{3}{|l|}{ Country-of-origin } \\
\hline $\mathrm{CHN}$ & - & - \\
\hline GER & $29.097 * * *(7.68)$ & $0.534 * * *(7.08)$ \\
\hline NZL & $13.486 * * *(4.69)$ & $0.232 * * *(4.05)$ \\
\hline FRA & $39.964 * * *(6.73)$ & $0.697 * * *(5.89)$ \\
\hline AU & $1.378(0.25)$ & $-0.036(-0.32)$ \\
\hline NED & $23.270 * * *(8.68)$ & $0.404 * * *(7.55)$ \\
\hline ESP & $34.431 * * *(7.38)$ & $0.546 * * *(5.87)$ \\
\hline \multicolumn{3}{|l|}{ B2C Platforms } \\
\hline COFCO I buy nets & - & - \\
\hline Yihaodian & $11.901 * * *(4.00)$ & $0.247 * * *(4.17)$ \\
\hline Jingdong & $12.138 * * *(4.23)$ & $0.250 * * *(4.37)$ \\
\hline Alibaba'sTmall Supermarket & $9.612 * * *(3.04)$ & $0.194 * * *(3.08)$ \\
\hline Suning Purchase & $8.587 * * *(2.83)$ & $0.196 * * *(3.24)$ \\
\hline \multicolumn{3}{|l|}{ Controlled variables } \\
\hline Salesize & $-0.006 * * *(-3.29)$ & $-0.000 * * *(-4.21)$ \\
\hline Shelflife & $0.595 * * *(2.66)$ & $0.018 * * *(4.13)$ \\
\hline Protein & $0.52(-1.36)$ & $0.017 * *(-2.22)$ \\
\hline Organic & $15.831 * * *(3.06)$ & $0.226 * *(2.19)$ \\
\hline Traceability & $0.237(0.13)$ & $0.005(0.14)$ \\
\hline Introduction_source & $1.44(0.81)$ & $0.017(0.49)$ \\
\hline Other_credentials & $-1.466(-0.91)$ & $-0.033(-1.03)$ \\
\hline Discount & $-5.064 * *(-2.37)$ & $-0.118 * * *(-2.76)$ \\
\hline Calcium & $-0.018 * *(-2.07)$ & $-0.000 * *(-2.56)$ \\
\hline Milk_fat & $0.009(-0.28)$ & $0.000(-0.43)$ \\
\hline Stage & $-5.169 * * *(-5.18)$ & $-0.120 * * *(-6.04)$ \\
\hline Constant & $39.009 * * *(5.42)$ & $3.435 * * *(23.91)$ \\
\hline $\mathrm{N}$ & 636 & 636 \\
\hline R-squared & 0.549 & 0.543 \\
\hline
\end{tabular}

products; it is not a comprehensive e-commerce platform, so its market awareness is not as high as that of the other four comprehensive platforms. Moreover, COFCO I buy nets has no self-support logistics outside Beijing, while the other four platforms all have self-logistics with better timeliness. Dairy prices vary by package size and shelflife; a larger package size decreases the price per unit for both categories. However, long shelflife leads to a higher price for infant formula but a lower price for UHT fluid milk.

The difference or opposite effect of $\mathrm{COO}$ on the prices of UHT fluid milk and infant formula might be due to two main reasons. Firstly, COO is a proxy of quality, and according to Zhang et al. (2018), Chinese consumers have better perceptions of the micro-image (or dairy industry image) of Germany compared with the Chinese dairy sector. The WTP for imported fluid milk (UHT, $200 \mathrm{ml}$ ) is more than $6 \mathrm{CNY}$, considerably more than the sale price. The difference between subjective WTP and objective selling price, or consumer surplus, will further boost the increase in fluid milk importation. Secondly, in terms of infant formula, due to the vulnerability of infants, strict quality and safety standards are needed. The melamine scandal first 
out broke in domestic infant formula, therefore the negative spillover effect on consumers' confidence has been long-lasting and still exists today. Moreover, the purchase of imported infant formula is also a matter of 'face/prestige'; many Chinese parents still hold the belief 'do not let the child lose at the starting line'. Therefore, the distrust in the domestic product, the special consumer group, the good reputation of imported dairy products, and conspicuous consumption will keep the price of imported infant formula high for a long period of time. It is also the main reason for the increase in infant formula purchasing through cross-border online shopping.

\section{Concluding discussion}

Dairy product prices vary substantially across product characteristics and categories. Dairy firms and dairy sectors, both at home and abroad, are constantly seeking to attract new consumers and increase their market share. This study investigated the price-COO relationships of dairy products and the implicit value of dairy product attributes in the online market, for both UHT fluid milk and infant formula.

The overall results suggest that the implicit value of COO for UHT fluid milk and infant formula have opposite outcomes. For UHT fluid milk, the imported milk from Germany and Spain has a negative implicit value; however, infant formula has a significant positive implicit value. The lack of popularity of imported UHT fluid milk leads to a negative or insignificant positive implicit price of imported UHT fluid milk, and the vulnerable target group and distrust in domestic infant formula contribute additional value to consumers for the imported infant formula.

This study has several implications. Firstly, as UHT fluid milk is a fast-growing product in China, but the COOL of the EU countries, Australia and New Zealand do not earn positive implicit value, to better satisfy Chinese consumers' diversified demand, it is feasible for these countries to adopt promotion strategies to improve the popularity and brand awareness of UHT fluid milk among Chinse consumers. For the Chinese dairy industry, awareness that the fluid UHT market will become more and more competitive in the context of free and open international trade and the rapid development of e-commerce is important, so they can consider shifting their marketing focus from UHT fluid milk to pasteurized milk and taking effective measures to advertise the benefits of pasteurized milk, to induce Chinese consumers to change their purchasing habits from UHT fluid milk to pasteurized milk with a short shelf life (15 days or 7 days). As refrigerator penetration is high and cold-chain transportation is well developed, it is plausible to foster the pasteurized milk consumption market. Secondly, compared with the EU countries, the COOL of infant formula from Australia and New Zealand does not earn a positive price premium. Though Chinese infant formula has price advantage, the market share is still low after the 2008 melamine issue in infant formula. Therefore, the Chinese dairy industry should make concerted efforts to develop brand equity and rejuvenate consumers' confidence in domestic infant formula.

\section{Acknowledgements}

The authors are grateful to Xucan Zhao for data collection. Supported by the Fundamental Research Funds for the Central Universities (lzujbky-2020-24; lzujbky-2020-kb29); the Major Program of the Key Research Institute of Chinese Ministry of Education (15JJD790032).

\section{Conflicts of interest}

The authors declare no conflicts of interest. The funders had no role in the design of the study; in the collection, analyses, or interpretation of data; in the writing of the manuscript; or in the decision to publish the results. 


\section{References}

Agrawal, J. and W.A. Kamakura. 1999. Country of origin: a competitive advantage? International Journal of Research in Marketing 16(4): 255-267. http://doi.org/10.1016/S0167-8116(99)00017-8

Bai, J., C. Zhang and J. Jiang. 2013. The role of certificate issuer on consumers' willingness-to-pay for milk traceability in China. Agricultural Economics 44(4-5): 537-544. https://doi.org/10.1111/agec.12037

Bai, J., T.I. Wahl and J.J. McCluskey. 2008. Fluid milk consumption in urban Qingdao, China. The Australian Journal of Agricultural and Resource Economics 52(2): 133-147. https://doi.org/10.1111/j.14678489.2008.00401.x

Bai, J., T.I. Wahl and P.R. Wandschneider. 2007. Valuing attributes of fluid milk using choice-based conjoint experimental design. Selected paper presented at the American Agricultural Economics Association Annual Meeting. July 29-August 1, 2007. Portland, OR, USA, p. 38. Available at: https://ageconsearch. umn.edu/record/9821

Baron, J., J.C. Hershey, and H. Kunreuther. 2000. Determinants of priority for risk reduction: the role of worry. Risk Analysis 20(4): 413-427. https://doi.org/10.1111/0272-4332.204041

Bonroy, O. and C. Constantatos. 2015. On the economics of labels: how their introduction affects the functioning of markets and the welfare of all participants. American Journal of Agricultural Economics 97(1): 239-259. https://doi.org/10.1093/ajae/aau088

Carew, R. and W.J. Florkowski. 2010. The importance of geographic wine appellations: hedonic pricing of burgundy wines in the British Columbia wine market. Canadian Journal of Agricultural Economics 58(1): 93-108. https://doi.org/10.1111/j.1744-7976.2009.01160.x

Cheng, L., C. Yin and H. Chien. 2014. Demand for milk quantity and safety in urban China: evidence from Beijing and Harbin. Australian Journal of Agricultural and Resource Economics 59(2): 275-287. https://doi.org/10.1111/1467-8489.12065

China Milk Yearbook Editorial Board (CMYEB). 2012. China dairy yearbook. China Agriculture Press, Beijing, China. (in Chinese)

Costanigro, M. and J.J. McCluskey. 2011. Hedonic price analysis in food markets. In: Lusk, J.L., J. Roosen and J.F. Shogren (eds.) The Oxford handbook of the economics of food consumption and policy. Oxford University Press, Oxford, UK, pp. 153-161. https://doi.org/10.1093/oxfordhb/9780199569441.013.0007

Costanigro, M., J.J. Mccluskey and C. Goemans. 2010. The economics of nested names: name specificity, reputations, and price premia. American Journal of Agricultural Economics 92(5): 1339-1350. https:// doi.org/10.1093/ajae/aaq065

Costanigro, M., J.J. Mccluskey and R.C. Mittelhammer. 2007. Segmenting the wine market based on price: hedonic regression when different prices mean different products. Journal of Agricultural Economics 58(3): 454-466. https://doi.org/10.1111/j.1477-9552.2007.00118.x

Dairy Association of China (DAC). 2018. China dairy trade monthly (2011-2018). Available at: https:// www.dac.org.cn/normal/newfxbg.jhtm (in Chinese)

Deselnicu, O.C., M. Costanigro, D.M. Souza-Monteiro and D.T. McFadden. 2013. A meta-analysis of geographical indication food valuation studies: what drives the premium for origin-based labels? Journal of Agricultural and Resource Economics 38(2): 204-219. https://ageconsearch.umn.edu/ record $/ 158285$

Ding, Y., M.V. Michele. 2019. Chinese consumers' preferences for quality signals on fresh milk: brand versus certification. Agribusiness 35(1): 1-17. https://doi.org/10.1002/agr.21604

Dong, X. and Z. Li. 2016. Food safety issues in China: a case study of the dairy sector. Journal of the Science of Food and Agriculture 96(1): 346-352. https://doi.org/10.1002/jsfa.7107

Dransfield, E., T.M. Ngapo, N.A. Nielsen, L. Bredahl, P. Sjödén, M. Magnusson, M.M. Campo and G.R. Nute. 2005. Consumer choice and suggested price for pork as influenced by its appearance, taste and information concerning country of origin and organic pig production. Meat Science 69(1): 61-70. https://doi.org/10.1016/j.meatsci.2004.06.006

Edenbrandt, A.K., S. Smed and L. Jansen. 2018. A hedonic analysis of nutrition labels across product types and countries. European Review of Agricultural Economics 45(1): 101-120. https://doi.org/10.1093/ erae/jbx025 
Ekeland, I., J.J. Heckman and L. Nesheim. 2002. Identifying hedonic models. American Economic Review 92(2): 304-309.

Ekeland, I., J.J. Heckman and L. Nesheim. 2004. Identification and estimation of hedonic models. Journal of Political Economy 112(S1): S60-S109.

Fuller, F., J. Huang, H. Ma and S. Rozelle. 2006. Got milk? The rapid rise of China's dairy sector and its future prospects. Food Policy 31(3): 201-215. https://doi.org/10.1016/j.foodpol.2006.03.002

Gao, Z., C. Li, J. Bai and J. Fu. 2016. Chinese consumer quality perception and preference of sustainable milk. China Economic Review 59: 100939. https://doi.org/10.1016/j.chieco.2016.05.004

Herrmann, R. and R. Teuber. 2012. Geographically differentiated products. In: J. Lusk, J. Roosen and J.F. Shogren (eds.) The Oxford handbook of the economics of food consumption and policy. Oxford University Press, Oxford, UK, pp. 811-842.

Huang, C.L. and B. Lin. 2007. A hedonic analysis of fresh tomato prices among regional markets. Review of Agricultural Economics 29(4): 783-800. https://doi.org/10.1111/j.1467-9353.2007.00387.x

Hussein, M. and I. Fraser. 2018. Hedonic analysis of consumers' valuation of country of origin of meat in the United Kingdom. Journal of Agricultural Economics 69(1): 182-198. https://doi.org/10.1111/14779552.12232

Jia, X., H. Luan, J. Huang, S. Li and S. Rozelle. 2014. Marketing raw milk from dairy farmers before and after the 2008 milk scandal in China: evidence from Greater Beijing. Agribusiness 30(4): 410-423. https://doi.org/10.1002/agr.21375

Jia, X., J. Huang, H. Luan, S. Rozelle and J. Swinnen. 2012. China's milk scandal, government policy and production decisions of dairy farmers: the case of Greater Beijing. Food Policy 37(4): 390-400. https://doi.org/10.1016/j.foodpol.2012.03.008

Jiang, Y., H.H. Wang, S. Jin and M. Delgado. 2019. The promising effect of green food label in the new online market. Sustainability 11(3): 796. https://doi.org/10.3390/su11030796

Ladd, G.W. and M.B. Martin. 1976. Prices and demands for input characteristics. American Journal of Agricultural Economics 58(1): 21-30. https://doi.org/10.2307/1238573

Ladd, G.W. and V. Suvannunt. 1976. A model of consumer goods characteristics. American Journal of Agricultural Economics 58(3): 504-510. https://doi.org/10.2307/1239267

Lancaster, K.J. 1966. A new approach to consumer theory. The Journal of Political Economy 74(2): 132157. https://doi.org/10.1086/259131

Lewis, K.E. and C. Grebitus. 2016. Why U.S. consumers support country of origin labeling: examining the impact of ethnocentrism and food safety. Journal of International Food \& Agribusiness Marketing 28(3): 254-270. https://doi.org/10.1080/08974438.2015.1110548

Lim, K.H., W. Hu, L.J. Maynard and E. Goddard. 2013. U.S. consumers' preference and willingness to pay for country-of-origin-labeled beef steak and food safety enhancements. Canadian Journal of Agricultural Economics 61(1): 93-118. https://doi.org/10.1111/j.1744-7976.2012.01260.x

Loureiro, M.L. and W.J. Umberger. 2003. Estimating consumer willingness to pay for country-of-origin labeling. Journal of Agricultural and Resource Economics 28(2): 287-301. https://doi.org/10.2307/40987187

Luo, M.M. 2011. Country-of-origin (COO) effect on Chinese consumers' evaluation of New Zealand milk powder. MSc-thesis, Auckland University of Technology, Auckland, New Zealand.

Newman, C.L., A.M. Turri, E. Howlett and A. Stokes. 2014. Twenty years of country-of-origin food labeling research: a review of the literature and implications for food marketing systems. Journal of Macromarketing 34(4): 505-519. https://doi.org/10.1177/0276146714529306

Ortega, D.L., H.H. Wang and N.J. Olynk Widmar. 2014. Aquaculture imports from Asia: an analysis of U.S. consumer demand for select food quality attributes. Agricultural Economics 45(5): 625-634. https:// doi.org/10.1111/agec.12111

Ortega, D.L., H.H. Wang, N.J. Olynk, L. Wu and J. Bai. 2012. Chinese consumers' demand for food safety attributes: a push for government and industry regulations. American Journal of Agricultural Economics 94(2): 489-495. https://doi.org/10.1093/ajae/aar074

Ortega, D.L., S.J. Hong, H.H. Wang and L. Wu. 2016. Emerging markets for imported beef in China: results from a consumer choice experiment in Beijing. Meat Science 121:317-323. https://doi.org/10.1016/j. meatsci.2016.06.032 
Peterson, H.H. and K. Yoshida. 2004. Quality perceptions and willingness-to-pay for imported rice in Japan. Journal of Agricultural and Applied Economics 36(1): 123-141. https://doi.org/10.1017/ s1074070800021908

Qiao, G., T. Guo and K.K. Klein. 2010. Melamine in Chinese milk products and consumer confidence. Appetite 55(2): 190-195. https://doi.org/10.1016/j.appet.2010.05.047

Quan, S., Y. Zeng, X. Yu and T. Bao. 2018. WTP for baby milk formula in China: using attribute nonattendance as a priori information to select attributes in choice experiment. Agribusiness 34(2): 300-320. https:// doi.org/10.1002/agr.21535

Tao, H., J. Luckstead, L. Zhao and C. Xie. 2016. Estimating restrictiveness of SPS measures for China's dairy imports. International Food and Agribusiness Management Review 19: 101-124. https://doi. org/10.22004/ag.econ.244619

Tsiros, M. and C.M. Heilman. 2005. The effect of expiration dates and perceived risk on purchasing behaviour in grocery store perishable categories. Journal of Marketing 69(2): 114-129. https://doi.org/10.1509/ jmkg.69.2.114.60762

Umberger, W.J., D.M. Feuz, C.R. Calkins and K. Killinger-Mann. 2002. U.S. consumer preference and willingness-to-pay for domestic corn-fed beef versus international grass-fed beef measured through an experimental auction. Agribusiness 18(4): 491-504. https://doi.org/10.1002/agr.10034

Wang, E., Z. Gao, Y. Heng and L. Shi. 2019. Chinese consumers' preferences for food quality test/measurement indicators and cues of milk powder: a case of Zhengzhou, China. Food Policy 89: 101791. https:// doi.org/10.1016/j.foodpol.2019.101791

Wang, Z., Y. Mao and F. Gale. 2008. Chinese consumer demand for food safety attributes in milk products. Food Policy 33(1): 27-36. https://doi.org/10.1016/j.foodpol.2007.05.006

Wu, B., Y. Chen, W. Si and H. Chien. 2014. A double-hurdle analysis of demand for powdered milk: evidence from household survey data in an urban Chinese province. Agribusiness 30(3): 331-344. https://doi. org/10.1002/agr.21373

Xie, J., Z. Gao, M. Swisher and X. Zhao. 2016. Consumers' preferences for fresh broccolis: interactive effects between country of origin and organic labels. Agricultural Economics 47(2): 181-191. https://doi. org/10.1111/agec.12193

Xiu, C. and K.K. Klein. 2010. Melamine in milk products in China: examining the factors that led to deliberate use of the contaminant. Food Policy 35(5): 463-470. https://doi.org/10.1016/j.foodpol.2010.05.001

$\mathrm{Yu}, \mathrm{X} .2012$. Productivity, efficiency and structural problems in Chinese dairy farms. China Agricultural Economic Review 4(2): 168-175. https://doi.org/10.1108/17561371211224755

Zhang, C., J. Bai and T.I. Wahl. 2012. Consumers' willingness to pay for traceable pork, milk, and cooking oil in Nanjing, China. Food Control 27(1): 21-28. https://doi.org/10.1016/j.foodcont.2012.03.001

Zhang, Y., S. Jin, Y.Y. Zhang and X. Yu. 2018. How country-of-origin influence Chinese consumers evaluation for imported milk? Selected paper presented at the International Association of Agricultural Economists (IAAE) 2018 Conference. July 28-August 2, 2018. Vancouver, British Columbia, Canada, pp. 38. Available at: https://ageconsearch.umn.edu/record/277193?ln=en 